Article

\title{
Drought in the Western United States: Its Connections with Large-Scale Oceanic Oscillations
}

\author{
Peng Jiang ${ }^{1,2}$, , Zhongbo Yu ${ }^{1,2, *}$ and Kumud Acharya ${ }^{2}$ \\ 1 State Key Laboratory of Hydrology-Water Resources and Hydraulic Engineering, Hohai University, \\ Nanjing 210098, China; peng.jiang@dri.edu or peng.hydro@gmail.com \\ 2 Division of Hydrologic Sciences, Desert Research Institute, Las Vegas, NV 89119, USA; \\ kumud.acharya@dri.edu \\ * Correspondence: zhongbo.zyu@gmail.com or zyu@hhu.edu.cn; Tel.: +1-702-468-1539
}

Received: 12 January 2019; Accepted: 12 February 2019; Published: 16 February 2019

\begin{abstract}
In this paper, we applied the Empirical Orthogonal Function (EOF) analysis on a drought index expressed as consecutive dry days (CDD) to identify the drought variability in western United States. Based on the EOF analysis, correlation maps were generated between the leading principle component (PC) of seasonal CDD and sea surface temperature (SST) anomalies to explore the dynamic context of the leading modes in CDD. The EOF analysis indicates that the spatiotemporal pattern of winter CDD is related to an integrated impact from El Niño-Southern Oscillation (ENSO), Pacific Decadal Oscillation (PDO), and Atlantic Multi-decadal Oscillation (AMO), while summer CDD is mainly controlled by PDO phases. We also calculated seasonal CDD anomalies during selected climatic phases to further evaluate the impacts of large-scale oceanic oscillation on the spatial pattern of droughts. We found that $\mathrm{AMO}+/ \mathrm{PDO}-$ will contribute to a consistent drought condition during the winter in the western United States. El Niño will bring a dry winter to the northern part of western United States while La Niña will bring a dry winter to the southern part. During El Niño years, the drought center changes with the type of El Niño events. Considering the future states of the examined ocean oscillations, we suggest possible drier than normal conditions in the western United States for upcoming decades, and moreover, an intensified drought for the coast areas of the north Pacific region and upper Mississippi River Basin.
\end{abstract}

Keywords: drought; spatiotemporal variability; ENSO; PDO; AMO; EOF analysis; western United States

\section{Introduction}

Drought, generally known as periods of short-term or prolonged deficiency in precipitation, is a recurring natural disaster that has considerable impacts on natural habitats, ecosystems, and many economic and social sectors worldwide [1]. The western United States, due to its geographic and climatological characteristics, rapidly changing social dynamics, and pressure from an expanding population, is particularly vulnerable to severe and sustained droughts [2-4]. Proxy climate indicators, such as lake-ocean sediments and tree rings, indicate that the western U.S. and surrounding regions have suffered from severe droughts, posing threats to social and ecological systems [5-9]. Moreover, recent meteorological records revealed an increasing frequency of drought, and this trend may continue in the future [10-12]. It is critical to know the evolution of drought in order to better plan for future drought disasters. Drought in the western United States originated from several large-scale ocean oscillations that reduced moisture transportation to the west. The prediction of future drought is therefore possible if the teleconnections between droughts and natural oscillations are thoroughly 
examined. This will provide guidance to deal with possible future droughts that would result in increased food, energy, and water insecurity [13-15].

Drought conditions have been generally associated with quasi-periodic variations in sea surface variables $[2,16]$. El Niño-Southern Oscillation (ENSO) is the best-known index of the ocean oscillations which are used for the evaluation of U.S. drought variation. It represents the periodical switch of cold and warm states in the tropical eastern Pacific Ocean (warm phase: El Niño; cold phase: La Niña). ENSO reflects the inter-annual variation of climate and is considered to be related to the spatial and temporal pattern of droughts in the western U.S. $[17,18]$. It is generally believed that El Niño is associated with below-average precipitation and droughts in the Pacific Northwest region [19], while La Niña contributes to below-average runoff and droughts in the southwestern United States [20,21]. However, these responses are not consistent through time [22,23] which suggests that ENSO should not be the only climate fluctuation that influences weather and climate patterns in the western United States.

Recent studies of instrumental records and tree ring reconstructions suggest that U.S. drought variability is mainly controlled by long-term temperature changes in the Atlantic and North Pacific Oceans $[2,24,25]$. North Pacific climate variations can be characterized by decadal switches (15-25 years) of warm/positive and cold/negative phases. The temperature variation happens above $20^{\circ} \mathrm{N}$ in the North Pacific Ocean and is known as Pacific Decadal Oscillation (PDO) [26]. The relationships between PDO and extreme precipitation or drought has been mostly studied in terms of its modulation effects on the ENSO-precipitation relationship [27-29]. Compared to PDO, North Atlantic climate variations are characterized by a longer period fluctuation of sea surface temperature (SST) and have a multi-decadal variation between warm/positive and cold/negative phases. This is known as Atlantic Multi-Decadal Oscillation (AMO), of which the periodical length is about 60 years [30,31]. The warm phase of AMO is accompanied by an increased probability of drought in the western United States [24]. Studies by Seager et al. [32] and Schubert et al. [33] indicate that the Atlantic SST anomalies contribute to sustaining drought in the western United States. Rather than AMO alone, the AMO modulation effect of ENSO on drought has been found to be more dominant [34].

As indicated by previous studies, droughts in the western U.S. may be controlled by the complicated interactions between the natural ocean oscillation discussed above. In other words, it is the integrated or modulated effects of these natural oscillations, rather than a single factor from them, that dominate the spatial and temporal patterns of droughts in the western U.S. To investigate the integrated effects of these oceanic oscillations on droughts, Drought-Related SST Forcing patterns are mostly examined using current climate models [35-37]. In this study, drought-related SST anomaly patterns are investigated using statistical methods. The aim of this study is to provide a comprehensive analysis of spatiotemporal variability of drought in the western United States and how it is impacted by the large-scale ocean oscillations in the Pacific and North Atlantic Ocean. We seek to: (1) Determine the connections between seasonal droughts and the examined ocean oscillations; (2) investigate the integrate effects of ocean oscillations on the spatial and temporal pattern of droughts; and (3) investigate the possible drought scenarios for the upcoming decades.

\section{Data and Methods}

Various indices have been developed to quantify a drought including the Palmer drought severity index (PSDI) [38], standardized precipitation index (SPI) [39,40], rainfall anomaly index (RAI) [41], etc. Each of them has its own strengths and weaknesses. For example, PSDI, probably the most widely used regional drought index, accounts for the temperature and soil characteristics. However, it is limited by (1) its inherent time scale, which is more suitable for agricultural impacts than hydrological droughts,

(2) assumptions that all precipitation is rain, which lead to unreliable values during winter seasons, and (3) slow responses to developing and diminishing droughts [42,43]. SPI is another widely used drought index. However, it is considered to be impacted by the length of the precipitation record and the type of probability distribution which is used to fit the precipitation series [44]. In this paper, consecutive 
dry days (CDD) are used to characterize the drought in the western United States. CDD is the duration index representing periods of excessive dryness and is calculated as maximum number of consecutive dry days (daily precipitation $<1 \mathrm{~mm}$ ). It represents the length of the longest dry spell during a certain period. In this study, the CDD of winter (October-March) and summer (April-September) was calculated. It is considered an integrated CDD period when the summer/winter CDD extends to the winter/summer period. It is worth noting here that CDD is selected not because it is better than PDSI in winter or SPI to describe drought. It is easy to calculate because it requires only the precipitation records at a daily temporal scale and is not limited by the length of the records. There is also no probability distribution involved in the calculating processes. On the other hand, CDD has not been widely used in drought evaluation; the application of CDD as a drought index could thus provide new and valuable results for comparisons of drought evaluations using different drought indices.

Grid CDD value was calculated using the NOAA Climate Prediction Center (CPC) Daily US Unified Precipitation Data (quality-checked to eliminate duplicated and overlapping stations) (CPC daily Unified Precipitation Data are available from [45]). Standard deviation and buddy checks were also applied to the datasets [46]. The daily data were gridded into a $0.25^{\circ} \times 0.25^{\circ}$ resolution over the region covering $140-60^{\circ} \mathrm{W}$ and $20-60^{\circ} \mathrm{N}$. The general coverage over the western United States could have been considered despite the fact that it had a sparser precipitation network than the eastern U.S. [47,48]. CPC daily precipitation spans from 1948 to present. However, the last decade of the CPC precipitation record was not included because of the apparent lack of consensus on the related AMO phase.

The leading modes of variability of CDD were investigated using Empirical Orthogonal Function (EOF) analysis [49]. This method aims to identify and extract the spatiotemporal modes which are ordered with respect to their representations of data variance and their measured "importance" or "contribution". For this study, the EOF analysis was conducted using the modified code writing in NCAR Command Language (NCL) (available from [50]). The square root of cosine of the latitude was applied to the calculated grid CDD for latitudinal distortions. The obtained EOFs displayed the spatial pattern while the corresponding Principle Components (PCs) exhibited the temporal pattern. The independence of eigenvectors was tested following a rule of thumb [51] and used to determine the number of retained EOFs.

To explore the relationships between the leading modes in CDD and SST, we generated a correlation map which showed the correlation coefficient between PCs and the SST time series. Our calculations were based on Kaplan SST V2 data [52]. The Kaplan SST V2 data consisted of monthly anomalies from 1856 to the present on a $5^{\circ} \times 5^{\circ}$ grid.

To examine the impacts of large scale ocean oscillation on drought conditions, we classified ENSO into three different ENSO types defined by Kim et al. (Table 1) [53]: Eastern Pacific warming (EPW) is generally regarded as conventional El Niño warming, which could be identified when Niño 3 region $\left(5^{\circ} \mathrm{N}-5^{\circ} \mathrm{S}, 150^{\circ} \mathrm{W}-90^{\circ} \mathrm{W}\right)$ warming is larger than 1 standard deviation (SD); Central Pacific warming $(\mathrm{CPW})$ is a recognized warming phase in the central Pacific region, which could be identified when Niño 4 region $\left(5^{\circ} \mathrm{N}-5^{\circ} \mathrm{S}, 160^{\circ} \mathrm{E}-150^{\circ} \mathrm{W}\right)$ warming is larger than $1 \mathrm{SD}$ and in the meantime, Niño 3 stays below this range; and Eastern Pacific cooling (EPC) is regarded as a conventional La Niña event, which could be defined when Niño 3 or Niño 3.4 region $\left(5^{\circ} \mathrm{N}-5^{\circ} \mathrm{S}, 170^{\circ} \mathrm{W}-120^{\circ} \mathrm{W}\right)$ is cooler than $1 \mathrm{SD}$. We also classified periods of positive (warm) and negative (cold) PDO and AMO combinations (Table 1) based on PDO (PDO time series are available from [54]) and AMO time series (AMO time series are available from [55]). Summer and winter CDD anomalies were calculated for these periods. A permutation re-sampling method was applied to test the statistical significance of the anomaly patterns [29]. We randomly sampled sets of years ( $N$ years) without replacement from the study period, $\mathrm{N}$ equals the number of years in each climatic phase (for example, $\mathrm{N}$ equals 9 for EPW as there are 9 years for EPW events). The sampling process was repeated 1000 times, and during each sampling process, we calculated the grid CDD anomaly (the CDD anomaly was obtained as the difference between CDD value of selected years and average CDD value of the whole study period) for each 
randomly sampled year. The seasonal average CDD anomaly is considered significantly anomalous at 0.1 level if its magnitude exceeds the 95th or 5th percentile of the CDD anomaly, determined by the random permutations.

Table 1. El Niño-Southern Oscillation (ENSO) event and Pacific Decadal Oscillation-Atlantic Multi-decadal Oscillation (PDO-AMO) combinations.

\begin{tabular}{cc}
\hline ENSO Event & Years \\
\hline EPW & $1951,1957,1963,1965,1972,1976,1982,1987,1997$ \\
CPW & $1969,1991,1994,2002,2004,2009$ \\
EPC & Years \\
\hline PDO-AMO Combinations & $1949,1955,1964,1970,1971,1973,1975,1985,1988,1995,1998,1999,2007$ \\
\hline AMO+ PDO- & $1964-1976$ \\
AMO- PDO- & $1977-1994$ \\
AMO- PDO+ & $1995-1998$ \\
AMO+ PDO+
\end{tabular}

\section{Results and Discussion}

\subsection{The Spatiotemporal Pattern of Droughts Based on EOF Analysis}

The EOF modes of CDD were evaluated for both summer and winter periods using the EOF analysis program coded with NCL. Figures 1a and 2a show EOF patterns determined by the EOF analysis program. Figures $1 \mathrm{c}$ and $2 \mathrm{c}$ are the associated time series (or principle component). Figures $1 \mathrm{~b}$ and $2 \mathrm{~b}$ are the correction maps generated by spatial plots of corrections between selected PC of seasonal CDD and grid sea surface temperature (SST) anomalies. The first EOF mode was selected for our analysis based on the independent test [51]. The other modes were not discussed because they were not independent or not distinct from their nearest neighbors. The first mode of winter CDD explains $31.2 \%$ of the total variance. The correlation map (Figure 1a) shows a north-south dipolar pattern. The north region is centered at the eastern part of the Pacific Northwest and western part of the Upper Mississippi River Basin. The larger south region covers most of the Great Basin and Colorado River Basin as well as southern California. The PC of the first mode negatively correlates with SST anomalies north of $20^{\circ} \mathrm{N}$ in the North Pacific Ocean (considered PDO), positively correlates with SST anomalies over the central eastern Pacific Ocean (considered ENSO SST field), and negatively correlates with SST anomalies over the North Atlantic Ocean (considered as AMO SST field). The complex relationships between the first PC of the winter CDD and SST anomalies indicate that spatiotemporal patterns of winter CDD result from an integrated effect of several large-scale ocean oscillations (Figure 1b).

For the summer period, the first EOF explains $13.5 \%$ of the total variance of summer CDD and displays a north-south dipolar spatial pattern. However, the north region is much larger than that of the winter CDD, which covers the whole area of the North Pacific Region and Upper Mississippi River Basin. In contrast, the south region is much smaller and centered in the southwestern arid desert region. The first PC of the summer CDD correlates with SST anomalies north of the North Pacific Ocean. However, it is not like the typical PDO SST map, as part of the summer SST anomaly lies south of the $20^{\circ} \mathrm{N}$ in the North Pacific Ocean. One possible reason is that there may be some modulated effects either from ENSO or other unknown factors on PDO, which needs future research. 
(a) Winter EOF1 (31.2\%)

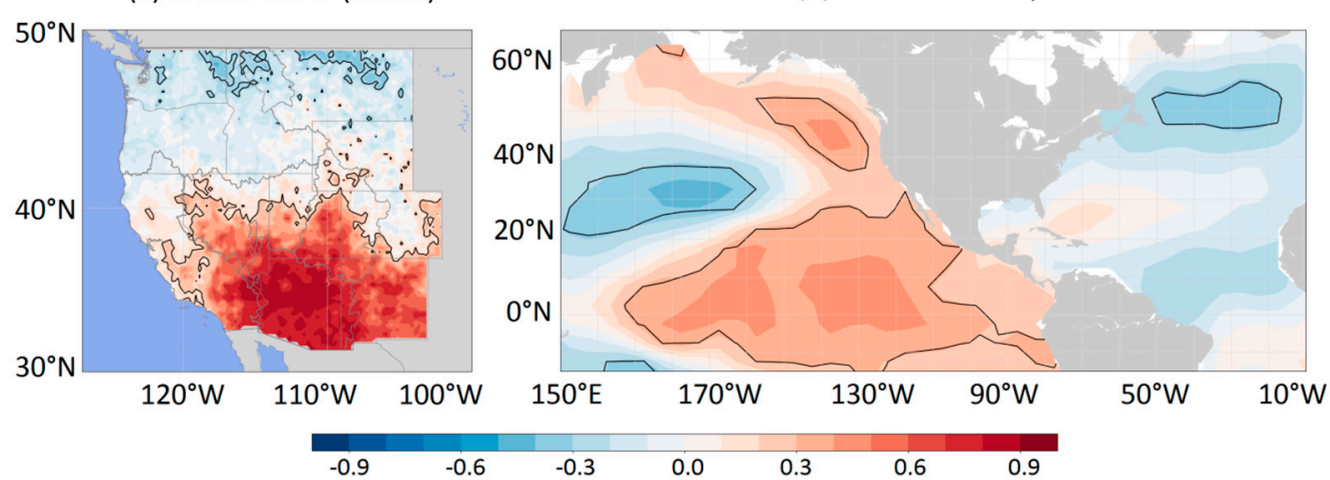

(c) Winter PC1 (b) Correlation Map

Correlation Coefficient

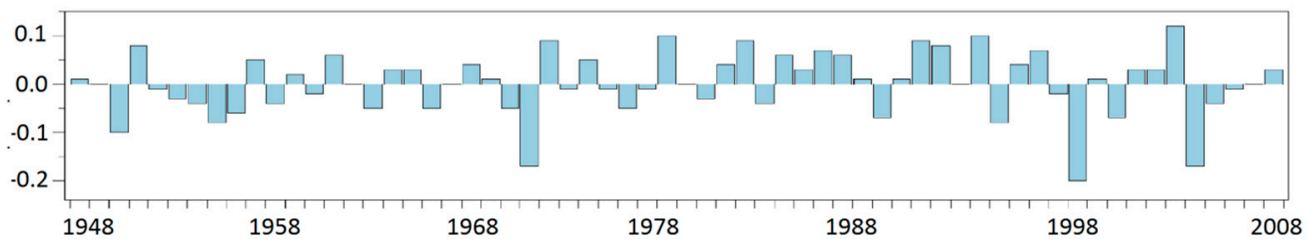

Figure 1. Empirical Orthogonal Function (EOF) analysis of winter consecutive dry days (CDD): (a) Spatial pattern of the winter CDD (1948-2009); (b) correlation coefficient between principle component (PC) and annual sea surface temperature (SST) anomalies; (c) the corresponding principal components of winter CDD. Contoured lines indicate regions with significant correlations at 0.05 level. The Western Pacific is not shown as there is no significant SST anomaly in this region.

(a) Summer EOF1 (13.5\%)

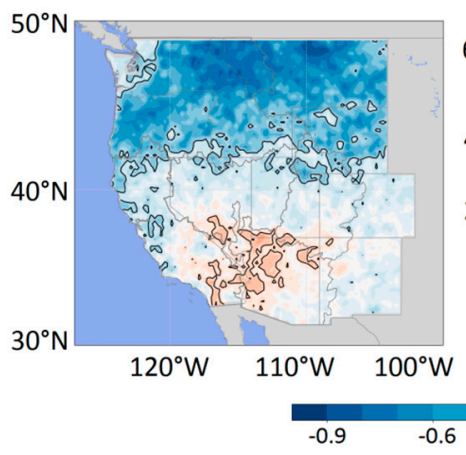

(b) Correlation Map

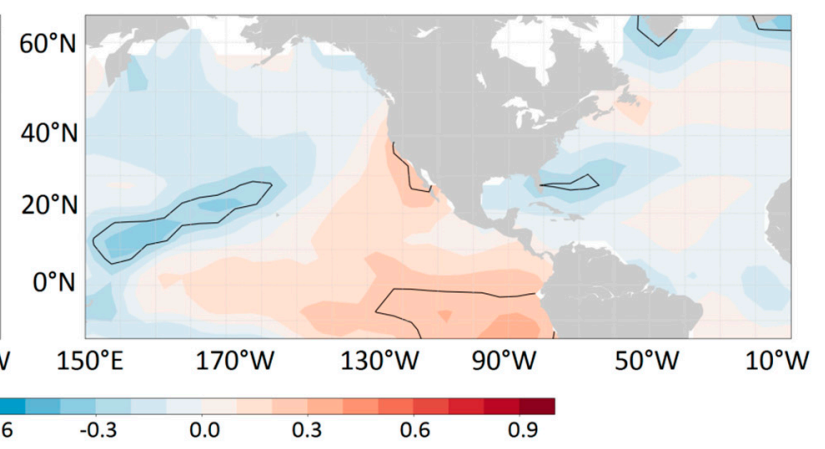

(c) Summer PC1 Correlation Coefficient

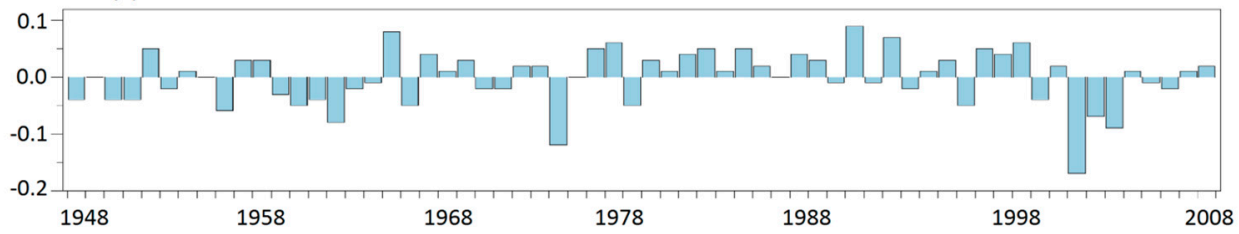

Figure 2. EOF analysis of summer CDD: (a) Spatial pattern of the summer CDD (1948-2009); (b) Correlation coefficient between PC and annual SST anomalies; (c) the corresponding principal components of summer CDD. Contoured lines indicate regions with significant correlations at 0.05 level. Western Pacific is not shown as there is no significant SST anomaly in this region.

\subsection{The Relation between Large-Scale Ocean Oscillations and Seasonal Droughts}

Figure 1 indicates a complicated relationship between winter CDD and multiple ocean oscillations. Winter CDD is related to both ENSO conditions and the climatic phases of PDO and AMO. Considering the different temporal scale between the ENSO phase and PDO-AMO phases, our analysis was 
conducted separately on different ENSO types and PDO-AMO combinations. ENSO is the dominant mode of inter-annual variability in the Tropics, and it has been connected to the drought variability of the western United States [17,56]. El Niño and La Niña represent warm/positive and cold/negative phases of ENSO. Traditional El Niño is characterized by eastern Pacific warming (EPW), but recent studies have identified a new type of El Niño with its maximum warming in the equatorial central Pacific (CPW) [57,58]. The two different El Niño events may lead to different atmospheric teleconnections and further impact on the delivery of water vapor [59]. To investigate how different ENSO types could influence the spatiotemporal distribution of CDD, three ENSO types were classified and listed in Table 1. The remaining years during the study period were considered normal years. The grid CDD anomaly during each ENSO type (for example, EPW) was calculated by subtracting the average CDD value during EPW years with the average CDD value during the whole period. Then, the standardized CDD anomaly was determined for each grid. Figure 3 is the map which displays the standardized CDD anomaly for each grid (the same as CPC grid). The spatial pattern of winter CDD anomalies displays an obvious north-south dipole pattern during EPW, CPW, and EPC years (Figure 3a-c). This pattern disappears during normal years (Figure 3d). During EPW and CPW years, the southwestern United States experience less than normal CDD while the northwestern states experience larger than normal CDD. In other words, the northwestern United States will suffer more drought events during El Niño years (EPW and CPW) while the southwestern United States will encounter more drought events during La Niña years (EPC). This is consistent with previous studies that El Niño is associated with below-average precipitation and droughts in the Pacific Northwest region while La Niña contributes to below-average runoff and droughts in the southwestern United States [19-21]. Although the spatial patterns of drought are similar in EPW and CPW years, the action centers do present some difference: During EPW years, the drought center is mainly located in the Upper Mississippi River Basin while in the CPW years, the drought center expands to the coast area of the north Pacific Region, which is consistent with conclusions from Yu and Zou that CPW produces an enhancing drying effect on the Ohio-Mississippi Valley and north Pacific Region [60]. Moreover, the wet region during $\mathrm{CPW}$ years is much larger to the north than that during EPW years. To evaluate the coupling effects of PDO and AMO, four periods are identified covering all possible groups of PDO and AMO phases (Table 1). The length of the AMO+/PDO+ group is only 3 yrs during the study period. As a result, we did not discuss the $\mathrm{CDD}$ anomalies during $\mathrm{AMO}+\mathrm{PDO}+$ as it may have introduced random errors to the analysis. The spatial pattern of drought is more consistent for the whole western United States when PDO and AMO are opposite phases (Figure 4a,b). Most of the western United States is under drought conditions (larger than normal CDD) during AMO+/PDOand wet conditions (less than normal CDD) during AMO-/PDO+ (Figure 4c). This confirms the findings from McCabe et al. [24] that the western U.S. bears a drought condition in AMO+ while the phase of PDO determines the location of the drought center (the drought center tends to be in the northern part during $\mathrm{PDO}+$ and the southern part during $\mathrm{PDO}-$ ). During $\mathrm{AMO}-/ \mathrm{PDO}-$, there is no obvious spatial pattern. The physical mechanism behind it is that the large-scale oceanic oscillations introduce or are associated with different pressure patterns that control the storm track position into the western U.S. El Niño is associated with deep Aleutian Low which forces the storm track southwards, the jet stream over the Pacific Ocean becomes less wavy and splits into a strengthening subtropical jet stream near the equator, and a weaker polar jet stream and can result in less storms and below-average precipitation across the Pacific Northwest during winter and early spring. In contrast, during La Nina years, the Pacific jet stream carves north and enters North America through the Pacific Northwest, diverting storms and precipitation away from the southwestern U.S., thus, bringing drier-than-average winter conditions to the Southwest. The physical mechanism of Atlantic SST anomalies on the western U.S. drought is still not clear based on current studies. It could be that Atlantic SST anomalies influence the southerly flow on the western flank of the North Atlantic and change the strength of westerlies across the mid-latitudes and thus, can have a modulation effect on precipitation patterns far away from the North Atlantic region. 
(a) EPW

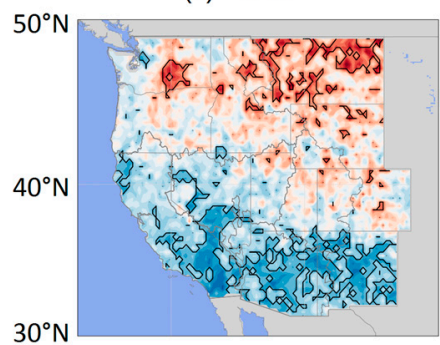

(c) EPC

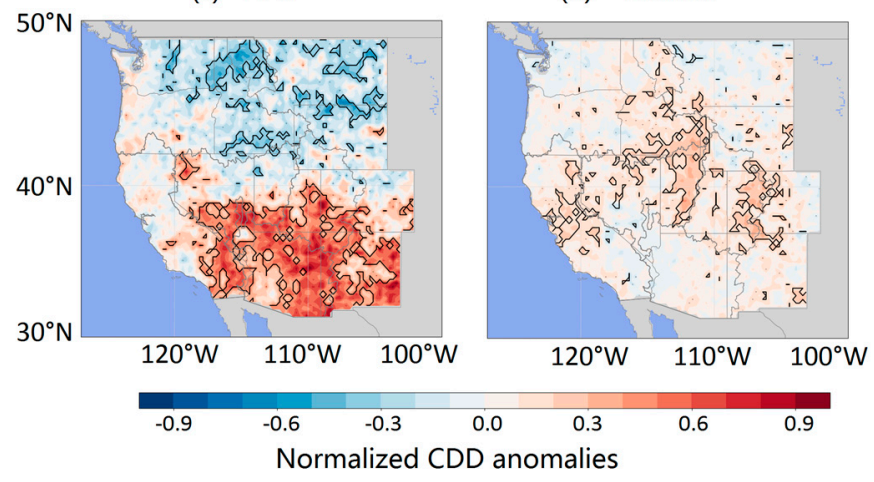

(b) CPW

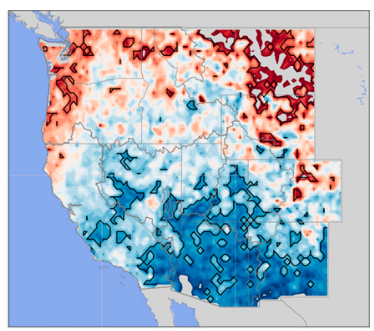

(d) Normal

Figure 3. Winter CDD anomalies (standardized) for (a) Eastern Pacific warming (EPW), (b) Central Pacific warming (CPW), (c) Eastern Pacific cooling (EPC), and (d) normal years. Contoured lines indicate regions with significant correlations at 0.1 level.

(a) $\mathrm{AMO}+\mathrm{PDO}-$

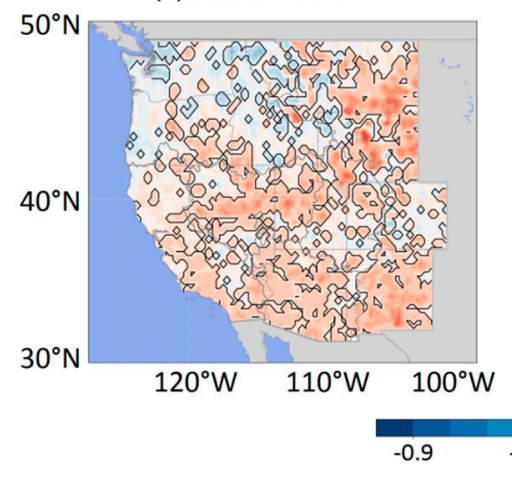

(b) AMO- PDO-

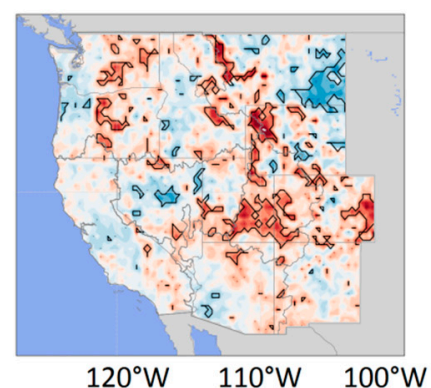

$120^{\circ} \mathrm{W} \quad 110^{\circ} \mathrm{W} \quad 100^{\circ} \mathrm{W}$ (c) $\mathrm{AMO}-\mathrm{PDO}+$

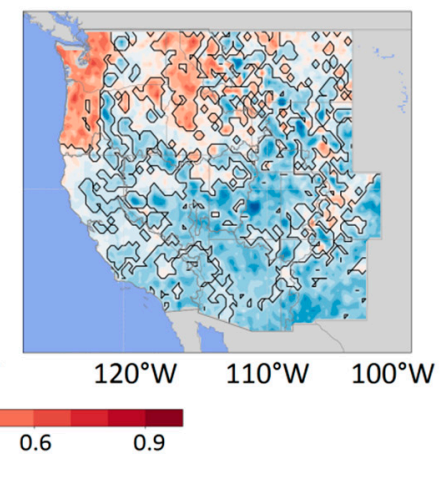

Figure 4. Winter CDD anomalies (standardized) for different AMO/PDO combinations. Contoured lines indicate regions with significant correlations at 0.1 level.

The summer CDD is mainly dominated by the PDO phase as indicated by the EOF analysis (Figure 2). As a result, the standard summer CDD anomalies during different PDO phases were calculated and presented in Figure 5. It shows that the western United States is under drought mode during summer when PDO is in the negative phase (cold phase) and wet mode when PDO is in the positive phase (warm phase). The spatial pattern is consistent for the whole western United States during each PDO phase. 
(a) PDO-

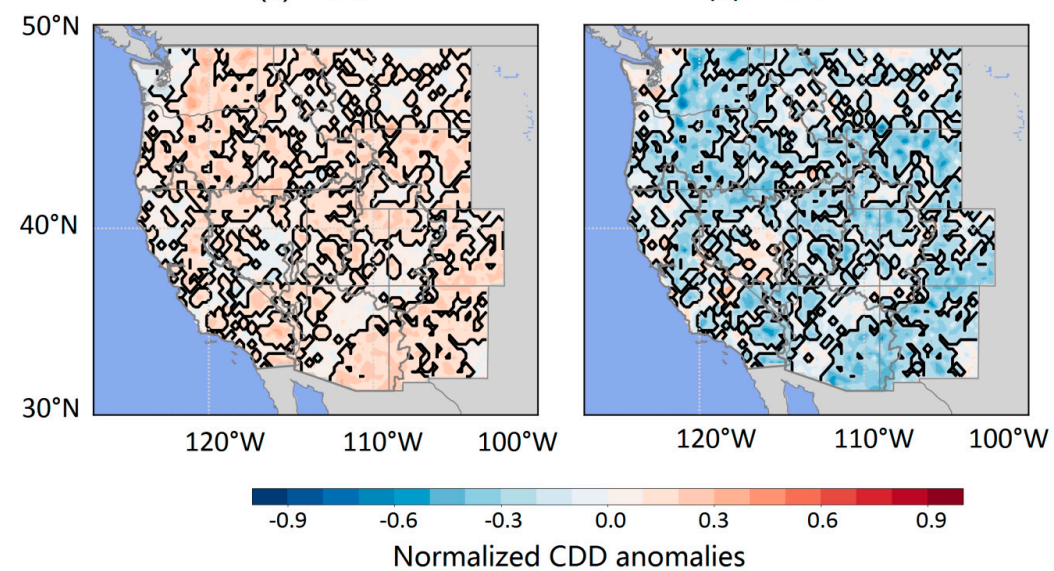

Figure 5. Summer CDD anomalies (standardized) for different PDO phases. Contoured lines indicate regions with significant correlations at 0.1 level.

\subsection{Future Drought Scenarios Based on the Prediction of Ocean Oscillations}

Based on the analysis, long term predictions of drought conditions in the western United States may be partly explained if future predictions of ocean oscillations are available. AMO is considered to have returned to its positive phase in 1995 and will continue to be positive for the next one to three decades [30,61-63]. Current negative PDO may continue based on simulations from multiple climate models [64,65]. Future forecasting of ENSO states are more reliable as short term $(<8$ months) [66-68] rather than long term predictions. The frequency of $\mathrm{CPW}$ has been predicted to increase due to various reasons suggested by Jin et al. [69], Timmermann et al. [70], and Yeh et al. [58]. However, one recent study by Cai et al. [71] shows that EPW exhibits a robust increased frequency due to global warming as predicted by current climate models. This finding is valuable in climatic research but also needs further assessment when other climate models are available. Regardless of the uncertainty of the future frequency of EPW and CPW, an increased El Niño frequency is expected in the future. In this situation, the drought conditions during summer will continue. The northwestern United States will be in a drought mode during winter and this drought condition will become even worse for the Upper Mississippi River Basin.

\section{Conclusions}

In summary, we have examined the spatiotemporal pattern of seasonal drought conditions (represented by CDD) in the western United States and how this pattern could be impacted by large scale ocean oscillations. We found that winter CDD is related to an integrated impact of ENSO, PDO, and AMO while summer CDD is mainly controlled by PDO phases. Our results also indicated that $\mathrm{AMO}+\mathrm{PDO}-$ will contribute to a consistent drought condition during winter over the whole western United States. El Niño will bring a dry winter to the northern part of the American West while La Niña will bring a dry winter to the Southwest, which confirms and strengthens findings from previous studies [19-21,24]. In particular, it is clear that the drought center and drought severity changes with the type of El Niño events: The more frequent shifts of El Niño locations from the Eastern Pacific region to the Central Pacific region may force the tropospheric jet streams further southward with profound impacts on the prevalence of extended droughts in the western U.S.

Moreover, the results could be used for long-term prediction of the seasonal drought conditions over the western U.S. The persistence of the current AMO+ state, the projection of negative PDO, and the increasing El Niño frequency will lead to a dry summer and winter in the western U.S. Moreover, the coastal area of the North Pacific region and Upper Mississippi River Basin will suffer from even worse dry conditions due to the increasing frequency of $\mathrm{CPW}$. 
It is worth noting that besides the ocean oscillations discussed in this study that influence the seasonal variations of droughts, other factors such as anthropogenic global warming and human water consumption style also appear to be important. Global warming is likely to enhance the evaporative demand and alter monsoon circulation and thus, is responsible for intensifying the meteorological drought [72-74]. Human water consumption, on the other hand, leads to more severe hydrological droughts $[75,76]$. These impacts on future drought could be investigated by numerical modeling or statistical analysis on current global climate model outputs [77]. However, it is still a big challenge to investigate the nonlinear interactions between these natural oscillations and human impacts. An extension of current research to investigate the integrated effects of the natural and the anthropogenic on future drought evolution is the subject of ongoing work.

Author Contributions: Conceptualization, P.J., Z.Y., and K.A.; methodology, P.J.; data curation, P.J.; writing—original draft preparation, P.J.; writing—review and editing, Z.Y. and K.A.

Funding: This work was supported by the National Key R\&D Program of China (Grant No. 2016YFC0402710); National Natural Science Foundation of China (Grant No. 51539003, 41761134090); and National Science Funds for Creative Research Groups of China (No. 51421006).

Acknowledgments: The first author is supported by the generosity and support of Sulo and Aileen Maki Endowment.

Conflicts of Interest: The authors declare no conflict of interest.

\section{References}

1. Heim, R. A review of twentieth-century drought indices used in the United States. Bull. Am. Meteorol. Soc. 2002, 83, 1149-1165. [CrossRef]

2. Hidalgo, H.G. Climate precursors of multidecadal drought variability in the western United States. Water Resour. Res. 2004, 40. [CrossRef]

3. Jiang, P.; Yu, Z.; Gautam, M.R. Pacific and atlantic ocean influence on the spatiotemporal variability of heavy precipitation in the Western United States. Glob. Planet. Chang. 2013, 109, 38-45.

4. Jiang, P.; Gautam, M.R.; Zhu, J.; Yu, Z. How well do the gcms/rcms capture the multi-scale temporal variability of precipitation in the Southwestern United States? J. Hydrol. 2013, 479, 75-85. [CrossRef]

5. Meko, D.; Stockton, C.W.; Boggess, W.R. The tree-ring record of severe sustained drought 1. J. Am. Water Resour. Assoc. 1995, 31, 789-801. [CrossRef]

6. Laird, K.R.; Cumming, B.F.; Wunsam, S.; Rusak, J.A.; Oglesby, R.J.; Fritz, S.C.; Leavitt, P.R. Lake sediments record large-scale shifts in moisture regimes across the northern prairies of North America during the past two millennia. Proc. Natl. Acad. Sci. USA 2003, 100, 2483-2488. [CrossRef] [PubMed]

7. Neff, J.; Ballantyne, A.; Farmer, G.; Mahowald, N.; Conroy, J.; Landry, C.; Overpeck, J.; Painter, T.; Lawrence, C.; Reynolds, R. Increasing eolian dust deposition in the Western United States linked to human activity. Nature Geosci. 2008, 1, 189. [CrossRef]

8. Stockton, C.W.; Meko, D.M. A long-term history of drought occurrence in Western United States as inferred from tree rings. Weatherwise 1975, 28, 244-249. [CrossRef]

9. Cook, E.R.; Seager, R.; Cane, M.A.; Stahle, D.W. North American drought: Reconstructions, causes, and consequences. Earth-Sci. Rev. 2007, 81, 93-134. [CrossRef]

10. Wehner, M.; Easterling, D.R.; Lawrimore, J.H.; Heim, R.R., Jr.; Vose, R.S.; Santer, B.D. Projections of future drought in the continental United States and Mexico. J. Hydrometeorol. 2011, 12, 1359-1377. [CrossRef]

11. Cayan, D.R.; Das, T.; Pierce, D.W.; Barnett, T.P.; Tyree, M.; Gershunov, A. Future dryness in the Southwest US and the hydrology of the early 21st century drought. Proc. Natl. Acad. Sci. USA 2010, 107, 21271-21276. [CrossRef] [PubMed]

12. Jiang, P.; Yu, Z.; Gautam, M.R.; Yuan, F.; Acharya, K. Changes of storm properties in the United States: Observations and multimodel ensemble projections. Glob. Planet. Chang. 2016, 142, 41-52. [CrossRef]

13. Hanjra, M.A.; Qureshi, M.E. Global water crisis and future food security in an era of climate change. Food Policy 2010, 35, 365-377. [CrossRef]

14. Bakker, K. Water security: Research challenges and opportunities. Science 2012, 337, 914-915. [CrossRef] [PubMed] 
15. Jiang, P.; Yu, Z.; Yuan, F.; Acharya, K. The multi-scale temporal variability of extreme precipitation in the source region of the yellow river. Water 2019, 11, 92. [CrossRef]

16. Namias, J. Some causes of United States drought. J. Clim. Appl. Meteorol. 1983, 22, 30-39. [CrossRef]

17. Cayan, D.R.; Redmond, K.T.; Riddle, L.G. ENSO and hydrologic extremes in the Western United States. J. Clim. 1999, 12, 2881-2893. [CrossRef]

18. Rajagopalan, B.; Cook, E.; Lall, U.; Ray, B.K. Spatiotemporal variability of enso and SST teleconnections to summer drought over the United States during the twentieth century. J. Clim. 2000, 13, 4244-4255. [CrossRef]

19. Morgenstern, K.; Black, T.A.; Humphreys, E.R.; Griffis, T.J.; Drewitt, G.B.; Cai, T.; Nesic, Z.; Spittlehouse, D.L.; Livingston, N.J. Sensitivity and uncertainty of the carbon balance of a Pacific Northwest Douglas-fir forest during an EL Niño/La Niña cycle. Agric. For. Meteorol. 2004, 123, 201-219. [CrossRef]

20. Cole, J.E.; Overpeck, J.T.; Cook, E.R. Multiyear La Niña events and persistent drought in the contiguous United States. Geophys. Res. Lett. 2002, 29, 25-21-25-24. [CrossRef]

21. Menking, K.M.; Anderson, R.Y. Contributions of La Niña and El Niño to middle holocene drought and late holocene moisture in the American Southwest. Geology 2003, 31, 937-940. [CrossRef]

22. Redmond, K.; Cayan, D. El Niño/southern oscillation and western climate variability. In Proceedings of the Sixth AMS Conference on Climate Variations, Nashville, TN, USA, 23-28 January 1994; pp. 141-145.

23. Trenberth, K.E. The definition of El Nino. Bull. Am. Meteorol. Soc. 1997, 78, 2771-2778. [CrossRef]

24. McCabe, G.J.; Palecki, M.A.; Betancourt, J.L. Pacific and atlantic ocean influences on multidecadal drought frequency in the United States. Proc. Natl. Acad. Sci. USA 2004, 101, 4136-4141. [CrossRef] [PubMed]

25. Brown, D.P.; Comrie, A.C. A winter precipitation 'dipole' in the Western United States associated with multidecadal ENSO variability. Geophys. Res. Lett. 2004, 31. [CrossRef]

26. Mantua, N.J.; Hare, S.R.; Zhang, Y.; Wallace, J.M.; Francis, R.C. A pacific interdecadal climate oscillation with impacts on salmon production. Bull. Am. Meteorol. Soc. 1997, 78, 1069-1080. [CrossRef]

27. Cai, W.; Van Rensch, P. The 2011 southeast queensland extreme summer rainfall: A confirmation of a negative pacific decadal oscillation phase? Geophys. Res. Lett. 2012, 39. [CrossRef]

28. Elison Timm, O.; Diaz, H.; Giambelluca, T.; Takahashi, M. Projection of changes in the frequency of heavy rain events over hawaii based on leading pacific climate modes. J. Geophys. Res. Atmos. 2011, 116. [CrossRef]

29. Wise, E.K. Spatiotemporal variability of the precipitation dipole transition zone in the western United States. Geophys. Res. Lett. 2010, 37. [CrossRef]

30. Enfield, D.B.; Mestas-Nuñez, A.M.; Trimble, P.J. The atlantic multidecadal oscillation and its relation to rainfall and river flows in the continental us. Geophys. Res. Lett. 2001, 28, 2077-2080. [CrossRef]

31. Kerr, R.A. A north atlantic climate pacemaker for the centuries. Science 2000, 288, 1984-1985. [CrossRef]

32. Seager, R.; Kushnir, Y.; Herweijer, C.; Naik, N.; Velez, J. Modeling of tropical forcing of persistent droughts and pluvials over western north America: 1856-2000. J. Clim. 2005, 18, 4065-4088. [CrossRef]

33. Schubert, S.D.; Suarez, M.J.; Pegion, P.J.; Koster, R.D.; Bacmeister, J.T. Causes of long-term drought in the us great plains. J. Clim. 2004, 17, 485-503. [CrossRef]

34. Mo, K.C.; Schemm, J.-K.E.; Yoo, S.-H. Influence of enso and the atlantic multidecadal oscillation on drought over the United States. J. Clim. 2009, 22, 5962-5982. [CrossRef]

35. Schubert, S.; Gutzler, D.; Wang, H.; Dai, A.; Delworth, T.; Deser, C.; Findell, K.; Fu, R.; Higgins, W.; Hoerling, M. A us clivar project to assess and compare the responses of global climate models to drought-related sst forcing patterns: Overview and results. J. Clim. 2009, 22, 5251-5272. [CrossRef]

36. Findell, K.L.; Delworth, T.L. Impact of common sea surface temperature anomalies on global drought and pluvial frequency. J. Clim. 2010, 23, 485-503. [CrossRef]

37. Burgman, R.; Seager, R.; Clement, A.; Herweijer, C. Role of tropical pacific ssts in global medieval hydroclimate: A modeling study. Geophys. Res. Lett. 2010, 37. [CrossRef]

38. Wayne, C.P. Meteorological Drought. US Weather Bureau Research Paper; 1965; 58. Available online: https:/ / www.ncdc.noaa.gov/temp-and-precip/drought/docs/palmer.pdf (accessed on 15 November 2018).

39. McKee, T.B.; Doesken, N.J.; Kleist, J. The relationship of drought frequency and duration to time scales. In Proceedings of the 8th Conference on Applied Climatology; American Meteorological Society: Boston, MA, USA, 1993; pp. 179-183.

40. McKee, T.B. Drought monitoring with multiple time scales. In Proceedings of the 9th Conference on Applied Climatology, Boston, MA, USA, 15-20 January 1995.

41. Van Rooy, M. A rainfall anomaly index independent of time and space. Notos 1965, 14, 6. 
42. Hayes, M.J.; Svoboda, M.D.; Wiihite, D.A.; Vanyarkho, O.V. Monitoring the 1996 drought using the standardized precipitation index. Bull. Am. Meteorol. Soc. 1999, 80, 429-438. [CrossRef]

43. Mishra, A.K.; Singh, V.P. A review of drought concepts. J. Hydrol. 2010, 391, 202-216. [CrossRef]

44. Wu, H.; Hayes, M.J.; Wilhite, D.A.; Svoboda, M.D. The effect of the length of record on the standardized precipitation index calculation. Int. J. Climatol. 2005, 25, 505-520. [CrossRef]

45. CPC Hourly US Precipitation. Available online: http://www.esrl.noaa.gov/psd/data/gridded/data.cpc_ hour.html (accessed on 12 January 2019).

46. Higgins, R.W.; Shi, W.; Yarosh, E.; Joyce, R. Improved United States precipitation quality control system and analysis. NCEP/Clim. Predict. Center Atlas 2000, 7, 40.

47. Chen, M.; Shi, W.; Xie, P.; Silva, V.B.; Kousky, V.E.; Wayne Higgins, R.; Janowiak, J.E. Assessing objective techniques for gauge-based analyses of global daily precipitation. J. Geophys. Res. Atmos. 2008, 113. [CrossRef]

48. Higgins, R.; Silva, V.; Kousky, V.; Shi, W. Comparison of daily precipitation statistics for the United States in observations and in the ncep climate forecast system. J. Clim. 2008, 21, 5993-6014. [CrossRef]

49. Lorenz, E.N. Empirical Orthogonal Functions and Statistical Weather Prediction; Massachusetts Institute of Technology: Cambridge, MA, USA, 1956.

50. NCL Graphics: EOFs. Available online: https://www.ncl.ucar.edu/Applications/eof.shtml (accessed on 12 January 2019).

51. North, G.R.; Bell, T.L.; Cahalan, R.F.; Moeng, F.J. Sampling errors in the estimation of empirical orthogonal functions. Mon. Weather Rev. 1982, 110, 699-706. [CrossRef]

52. Kaplan, A.; Cane, M.A.; Kushnir, Y.; Clement, A.C.; Blumenthal, M.B.; Rajagopalan, B. Analyses of global sea surface temperature 1856-1991. J. Geophys. Res. Oceans 1998, 103, 18567-18589. [CrossRef]

53. Kim, H.-M.; Webster, P.J.; Curry, J.A. Impact of shifting patterns of pacific ocean warming on north atlantic tropical cyclones. Science 2009, 325, 77-80. [CrossRef] [PubMed]

54. Pacific Decadal Oscillation (PDO). Available online: https://www.esrl.noaa.gov/psd/gcos_wgsp/ Timeseries / PDO/ (accessed on 12 January 2019).

55. AMO (Atlantic Multidecadal Oscillation) Index. Available online: https://www.esrl.noaa.gov/psd/data/ timeseries / AMO/ (accessed on 12 January 2019).

56. Jiang, P.; Yu, Z.; Gautam, M.R.; Acharya, K. The spatiotemporal characteristics of extreme precipitation events in the western United States. Water Resour. Manag. 2016, 30, 4807-4821. [CrossRef]

57. Xiang, B.; Wang, B.; Li, T. A new paradigm for the predominance of standing central pacific warming after the late 1990s. Clim. Dyn. 2013, 41, 327-340. [CrossRef]

58. Yeh, S.-W.; Kug, J.-S.; Dewitte, B.; Kwon, M.-H.; Kirtman, B.P.; Jin, F.-F. El niño in a changing climate. Nature 2009, 461, 511. [CrossRef]

59. Garfinkel, C.I.; Hurwitz, M.M.; Oman, L.D.; Waugh, D.W. Contrasting effects of central pacific and eastern pacific el niño on stratospheric water vapor. Geophys. Res. Lett. 2013, 40, 4115-4120. [CrossRef]

60. Yu, J.-Y.; Zou, Y. The enhanced drying effect of central-pacific el niño on us winter. Environ. Res. Lett. 2013, 8, 014019. [CrossRef]

61. Schlesinger, M.E.; Ramankutty, N. An oscillation in the global climate system of period 65-70 years. Nature 1994, 367, 723. [CrossRef]

62. Sutton, R.T.; Hodson, D.L. Atlantic ocean forcing of north American and european summer climate. Science 2005, 309, 115-118. [CrossRef] [PubMed]

63. Enfield, D.B.; Cid-Serrano, L. Projecting the risk of future climate shifts. Int. J. Climatol. J. R. Meteorol. Soc. 2006, 26, 885-895. [CrossRef]

64. Mochizuki, T.; Ishii, M.; Kimoto, M.; Chikamoto, Y.; Watanabe, M.; Nozawa, T.; Sakamoto, T.T.; Shiogama, H.; Awaji, T.; Sugiura, N. Pacific decadal oscillation hindcasts relevant to near-term climate prediction. Proc. Natl. Acad. Sci. USA 2010, 107, 1833-1837. [CrossRef] [PubMed]

65. Lapp, S.L.; St. Jacques, J.M.; Barrow, E.M.; Sauchyn, D.J. Gcm projections for the pacific decadal oscillation under greenhouse forcing for the early 21st century. Int. J. Climatol. 2012, 32, 1423-1442. [CrossRef]

66. Collins, M.; Frame, D.; Sinha, B.; Wilson, C. How far ahead could we predict el nino? Geophys. Res. Lett. 2002, 29, 130-131-130-134. [CrossRef]

67. Mazzarella, A.; Giuliacci, A.; Liritzis, I. On the 60-month cycle of multivariate enso index. Theor. Appl. Climatol. 2010, 100, 23-27. [CrossRef] 
68. Mazzarella, A.; Giuliacci, A.; Scafetta, N. Quantifying the multivariate enso index (mei) coupling to $\mathrm{CO}^{2}$ concentration and to the length of day variations. Theor. Appl. Climatol. 2013, 111, 601-607. [CrossRef]

69. Jin, F.F.; An, S.I.; Timmermann, A.; Zhao, J. Strong el niño events and nonlinear dynamical heating. Geophys. Res. Lett. 2003, 30, 20-21. [CrossRef]

70. Timmermann, A.; Oberhuber, J.; Bacher, A.; Esch, M.; Latif, M.; Roeckner, E. Increased el niño frequency in a climate model forced by future greenhouse warming. Nature 1999, 398, 694. [CrossRef]

71. Cai, W.; Wang, G.; Dewitte, B.; Wu, L.; Santoso, A.; Takahashi, K.; Yang, Y.; Carréric, A.; McPhaden, M.J. Increased variability of eastern pacific el niño under greenhouse warming. Nature 2018, 564, 201-206. [CrossRef] [PubMed]

72. Dai, A. Drought under global warming: A review. Wiley Interdiscip. Rev. Clim. Chang. 2011, 2, 45-65. [CrossRef]

73. Dai, A. Increasing drought under global warming in observations and models. Nat. Clim. Chang. 2013, 3, 52. [CrossRef]

74. Sheffield, J.; Wood, E.F.; Roderick, M.L. Little change in global drought over the past 60 years. Nature 2012, 491, 435. [CrossRef] [PubMed]

75. Wada, Y.; Van Beek, L.P.; Wanders, N.; Bierkens, M.F. Human water consumption intensifies hydrological drought worldwide. Environ. Res. Lett. 2013, 8, 034036. [CrossRef]

76. Wanders, N.; Wada, Y. Human and climate impacts on the 21st century hydrological drought. J. Hydrol. 2015, 526, 208-220. [CrossRef]

77. Yang, T.; Zhang, Q.; Chen, Y.D.; Tao, X.; Xu, C.Y.; Chen, X. A spatial assessment of hydrologic alteration caused by dam construction in the middle and lower yellow river, china. Hydrol. Process. Int. J. 2008, 22, 3829-3843. [CrossRef]

(C) 2019 by the authors. Licensee MDPI, Basel, Switzerland. This article is an open access article distributed under the terms and conditions of the Creative Commons Attribution (CC BY) license (http://creativecommons.org/licenses/by/4.0/). 